\title{
Multiple transgressions and slow evolution shape the phylogeographic pattern of the blind cave-dwelling shrimp Typhlocaris
}

\author{
Tamar Guy-Haim ${ }^{\text {Corresp., }}{ }^{1,2}$ ， Noa Simon-Blecher ${ }^{3}$, Amos Frumkin ${ }^{4}$ ， Israel Naaman ${ }^{4}$, Yair Achituv ${ }^{3}$ \\ 1 Marine Ecology, GEOMAR, Helmholtz Centre for Ocean Research, Kiel, Germany \\ 2 National Institute of Oceanography, Israel Oceanographic and Limnological Research, Haifa, Israel \\ 3 The Mina and Everard Goodman Faculty of Life Sciences, Bar-llan University, Ramat Gan, Israel \\ 4 Institute of Earth Science, Hebrew University of Jerusalem, Jerusalem, Israel \\ Corresponding Author: Tamar Guy-Haim \\ Email address: tguy-haim@geomar.de
}

Background. Aquatic subterranean species often exhibit disjunct distributions, with high level of endemism and small range, shaped by vicariance, limited dispersal, and evolutionary rates. We studied the disjunct biogeographic patterns of an endangered blind cave shrimp, Typhlocaris, and identified the geological and evolutionary processes that have shaped its divergence pattern.

Methods. We collected Typlocaris specimens of three species (T. galilea, T. ayyaloni, and T. salentina), originating from subterranean groundwater caves by the Mediterranean Sea, and used three mitochondrial genes $(12 \mathrm{~S}, 16 \mathrm{~S}, \mathrm{COI})$ and four nuclear genes (18S, 28S, ITS, H3) to infer their phylogenetic relationships. Using the radiometric dating of a geological formation (Bira) as a calibration node, we estimated the divergence times of the Typhlocaris species and the molecular evolution rates.

Results. The multi-locus ML/Bayesian trees of the concatenated seven gene sequences showed that $T$. salentina (Italy) and T. ayyaloni (Israel) are sister species, both sister to T. galilea (Israel). The divergence time of $T$. ayyaloni and $T$. salentina from $T$. galilea was 5.7 [4.4-6.9] Ma according to COI, and 5.8 [3.57.2] $\mathrm{Ma}$ according to $16 \mathrm{~S}$, based on Bira calibration. The computed interspecific evolutionary rates were 0.0077 substitutions/Myr for $\mathrm{COI}$, and 0.0046 substitutions/Myr for $16 \mathrm{~S}$.

Discussion. Two consecutive vicariant events have shaped the phylogeographic patterns of Typhlocaris species. First, $T$. galilea was tectonically isolated from its siblings in the Mediterranean Sea by the arching uplift of the central mountain range of Israel ca. $7 \mathrm{Ma}$. Secondly, T. ayyaloni and T. salentina were stranded and separated by a marine transgression ca. $6 \mathrm{Ma}$, occurring just before the Messinian Salinity Crisis. Our estimated molecular evolution rates were in one order of magnitude lower than the rates of closely related crustaceans, as well as of other stygobiont species. We suggest that this slow evolution reflects the ecological conditions prevailing in the highly isolated subterranean water bodies inhabited by Typhlocaris. 
1 TITLE:

2

4 Short title: Mediterranean stygobiont phylogeography

\section{5}

6

7 Tamar Guy-Haim ${ }^{1,2^{*}}$, Noa Simon-Blecher ${ }^{3}$, Amos Frumkin $^{4}$, Israel Naaman ${ }^{4}$, Yair Achituv ${ }^{3}$

\section{8}

9

10 Germany.

112 Israel Oceanographic and Limnological Research, National Institute of Oceanography. P.O. Box 8030, Haifa

1231080 , Israel.

$13{ }^{3}$ The Mina and Everard Goodman Faculty of Life Sciences, Bar Ilan University, Ramat Gan 529002 Israel.

$14{ }^{4}$ Institute of Earth Science, The Hebrew University of Jerusalem, Jerusalem 9190401 Israel.

15

16 *Corresponding author: Tamar Guy-Haim, GEOMAR, Helmholtz Centre of Ocean Research

17 Kiel, Düsternbrooker Weg 20, Kiel 24105, Germany.tguy-haim@geomar.de. Office: +49 431

18 6004508, Mobile: +49 16 24037340, Fax: +49 4316001671

19

20

Manuscript type: Research Article 


\section{ABSTRACT}

22 Background. Aquatic subterranean species often exhibit disjunct distributions, with high level 23 of endemism and small range, shaped by vicariance, limited dispersal, and evolutionary rates.

24 We studied the disjunct biogeographic patterns of an endangered blind cave shrimp, Typhlocaris, 25 and identified the geological and evolutionary processes that have shaped its divergence pattern.

26 Methods. We collected Typlocaris specimens of three species (T. galilea, T. ayyaloni, and T. 27 salentina), originating from subterranean groundwater caves by the Mediterranean Sea, and used 28 three mitochondrial genes $(12 \mathrm{~S}, 16 \mathrm{~S}, \mathrm{COI})$ and four nuclear genes (18S, 28S, ITS, H3) to infer 29 their phylogenetic relationships. Using the radiometric dating of a geological formation (Bira) as 30 a calibration node, we estimated the divergence times of the Typhlocaris species and the 31 molecular evolution rates.

32 Results. The multi-locus ML/Bayesian trees of the concatenated seven gene sequences showed that $T$. salentina (Italy) and T. ayyaloni (Israel) are sister species, both sister to T. galilea (Israel).

34 The divergence time of T. ayyaloni and T. salentina from T. galilea was 5.7 [4.4-6.9] Ma 35 according to COI, and 5.8 [3.5-7.2] Ma according to $16 \mathrm{~S}$, based on Bira calibration. The computed interspecific evolutionary rates were 0.0077 substitutions/Myr for COI, and 0.0046 substitutions/Myr for $16 \mathrm{~S}$.

Discussion. Two consecutive vicariant events have shaped the phylogeographic patterns of Typhlocaris species. First, T. galilea was tectonically isolated from its siblings in the Mediterranean Sea by the arching uplift of the central mountain range of Israel ca. $7 \mathrm{Ma}$. Secondly, T. ayyaloni and T. salentina were stranded and separated by a marine transgression ca. $6 \mathrm{Ma}$, occurring just before the Messinian Salinity Crisis. Our estimated molecular evolution rates were in one order of magnitude lower than the rates of closely related crustaceans, as well as of other stygobiont species. We suggest that this slow evolution reflects the ecological conditions prevailing in the highly isolated subterranean water bodies inhabited by Typhlocaris. 


\section{INTRODUCTION}

48 The biogeographic distribution patterns of populations of aquatic subterranean organisms

49 (stygobionts) are characterized by a small range and high degree of endemism, originating from

50 limited dispersal abilities and vicariant events, isolating the subterranean basins (Christman et al.

51 2005; Culver \& Holsinger 1992; Culver et al. 2009; Culver \& Sket 2000; Gibert \& Deharveng

52 2002; Porter 2007). Sometimes the entire distribution of a stygobiont species is restricted to a

53 single subterranean water body, exposing it to a substantial risk of extinction due to natural and

54 anthropogenic pressures such as salt water intrusion, pollution, climate change, and overexploitation of groundwater for drinking and agricultural purposes, resulting in habitat

56 destruction (Culver \& Pipan 2009; Danielopol et al. 2003; Gibert et al. 2009).

57 The aquatic subterranean fauna of the Levant is comprised of typical stygofauna (Por et al. 2013). Among them are at least four crustaceans, found in sites located along the Dead Sea Rift valley with congeneric taxa found in the Mediterranean coastal plain and even in brackish groundwater in the south of Israel. These obligate stygobionts are regarded as relicts of extinct marine fauna of ancient Mediterranean transgressions (Por 1963). The most prominent members of this faunal assemblage are the large blind prawns of the genus Typhlocaris. Four species of this genus are known from four localities around the east Mediterranean Sea (Figure 1). Each locality is inhabited by a different species with no congenerics in the open sea. Two species are known from Israel: T. galilea (Calman 1909) from the Tabgha spring on Lake Kinneret shore, and the recently discovered T. ayyaloni (Tsurnamal 2008), found in the karstic underground basin near Ramla, named Ayyalon cave, about $200 \mathrm{~km}$ south of Tabgha. The third species - T. salentina Caroli, 1923 was described from the Zinzulusa cave in Southern Italy and was recently found in other two caves in southern Italy (Froglia \& Ungaro 2001). The fourth species, T. lethaea Parisi, 1921 is known from Libya near Benghazi. In the IUCN Red List of Threatened Species, T. galilea and T. ayyaloni are defined as endangered, and T. salentina as vulnerable. No data later than 1960 on T. lethaea is available (De Grave 2013). the Mediterranean Sea that occurred during the Messinian Salinity Crisis (MSC), 5.96 to 5.33 
76 Mediterranean Sea waters when the Mediterranean desiccated and transformed to small

77 hypersaline basins. During this crisis, the Mediterranean Sea lost almost all its Miocene tropical

78 fauna, including those able to colonize subterranean waters (Por 1975; Por 1986; Por \&

79 Dimentman 2006). Therefore, the stranding of the Typhlocaris species and the separation from

80 their common ancestor have likely preceded the MSC.

81 Two scenarios were proposed to explain the disjunct distribution of Typhlocaris $(\mathrm{H} 1$ and $\mathrm{H} 2$,

82 Figure 2). Por $(1963 ; 1975 ; 2006)$ suggested that Typhlocaris species have been stranded along

83 the shores of a peri-Mediterranean Pliocene transgression, during the Zanclean (5.3-3.6 Ma). The

84 timing of this scenario contradicts the pre-MSC stranding described above. According to Por

85 (1963), the Typhlocaris species expanded their distribution into the Jordan valley when it was

86 submerged for a brief period during the Zanclean marine transgression. The coastal plain was

87 also submerged by this transgression that possibly also covered a part of the south of Israel (Por

88 1963). Those faunal elements were left behind when the shore has retreated during the regression

89 that followed the transgression in the early Pliocene. Similarly, Horowitz (2001) suggested that

90 during the Pliocene, two successive transgressive cycles have occurred in the Zanclean and the

91 Piacenzian, separated by a regression. Thus, according to this scenario, T. galilea and T. ayyaloni

92 were separated together or at successive events from the Mediterranean fauna, and are thus sister

93 taxa (H1, Figure 2).

94 A recent study of the eastern Galilee (Rozenbaum et al. 2016) suggests a second scenario (H2,

95 Figure 2). The marine transgression into the Dead Sea valley, bringing along T. galilea, was

96 associated with a subsidence of the eastern Galilee. The Dead Sea rift valley, accommodating

97 several water bodies, became tectonically isolated from the Mediterranean by the arching uplift

98 of the central mountain range of Israel. This uplift also divided the groundwater basins of the

99 Dead Sea basin from those associated with the Mediterranean, thus resulting in an earlier

100 divergence of $T$. galilea than the divergence of its sister species. Contrastingly, the other three

101 Typhlocaris species were found in coastal to inland aquifers that are not isolated from the

102 Mediterranean by a tectonic barrier. They could be stranded in the coastal aquifers by a

103 regression that was not necessarily associated with a tectonic event. This scenario (H2) is

104 supported by the finding of marine macrofossils within the late Miocene Bira Formation of the

105 SE Galilee-Jordan valley indicating its association with a marine transgression (Shaked-Gelband 
106 et al. 2014). Ar-Ar dates of volcanics interbedded within the Bira Formation show that the

107 earliest marine invasion into the SE Galilee-Jordan valley happened between 11 and $10 \mathrm{Ma}$

108 (Rozenbaum et al. 2016; for earlier dating see Shaliv 1989). Ongoing subsidence of the SE

109 Galilee basin, coupled with rising sea level, resulted in the invasion of the Mediterranean water

110 and establishment of a seaway that connected it to the evolving Dead Sea Rift in the east, as

111 represented by parts of the Bira Formation. Seawater could have flowed to the SE Galilee basin

112 either due to global sea level rise above the low barrier near the coastline or due to tectonic

113 subsidence of the Yizre'el Valley which had already started to develop. The detachment of this

114 region from the Mediterranean occurred ca. 7Ma, when the Mediterranean Sea level started

115 falling during the Messinian, followed by freshwaters gradually replacing the saline waters of the

116 Bira lagoon. Thus, the main marine ingression is constrained to the Tortonian, prior to the MSC.

117 Further to the NE, within the Hula valley, Syria and Lebanon, there is no indication of this

118 marine transgression, demonstrating that the marine water came from the Mediterranean and not

119 from the NE (Rozenbaum et al. 2016). This is consistent with the circum-Mediterranean

120 distribution of the four Typhlocaris species.

121 The main objectives of our study were: (1) to reveal the phylogenetic relationships of the

122 Typhlocaris species, and to use these patterns to (2) infer the geological and evolutionary

123 processes that have shaped their divergence patterns.

\section{MATERIALS \& METHODS}

125 Species sampling, genes and outgroup selection

126 Specimens of T. galilea were collected by us, in the covered pool collecting the water of Tabgha

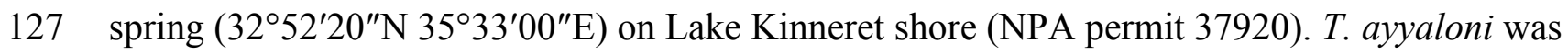

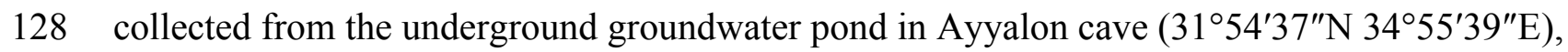

129 two specimens of T. salentina were provided by Dr. G. Messana Firenze - Italy from two caves

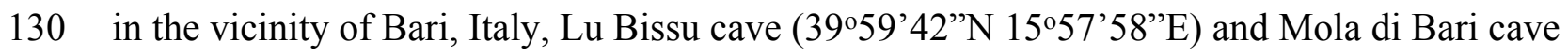

131 (41 $\left.{ }^{\circ} 03^{\prime} 36^{\prime \prime} \mathrm{N} 17^{\circ} 05^{\prime} 24^{\prime \prime} \mathrm{E}\right)$. All samples were fixed and stored in $95 \%$ ethanol at $-20^{\circ} \mathrm{C}$ until

132 DNA extraction. The locality of the fourth species, T. lethaea, is restricted to Lete Cave, near

133 Benghazi, Libya, and is not accessible. The two specimens of T. lethaea, collected by Parisi a 
134 century ago (1921), and stored in the Museum National d'Histoire Naturelle, Paris, did not yield 135 DNA.

\section{DNA extraction, amplification and sequencing}

137 DNA was extracted using Macherey-Nagel genomic DNA isolation kit (Düren, Germany),

138 following the manufacturer's recommended protocol. The primers used for gene amplification

139 are detailed in the Supplemental Information, including both primers from former studies and 140 newly designed primers for this study (Table S1). REDTaq ReadyMix R2523 (Sigma-Aldrich,

141 St. Louis, MO) was used for sequence amplification by PCR (Saiki et al. 1988). Amplification

142 was carried out in a personal combi-thermocycler (Biometra, Germany) according to the profiles

143 listed in Table S1. PCR products were purified by centrifugation using a High Pure PCR product

144 purification kit (Roche Diagnostics GmbH, Mannheim, Germany) or by Mclab laboratories (San

145 Francisco, California). PCR products were sequenced on both strands using an ABI PRISM 3100

146 Genetic Analyzer (Applied Biosystems) by McLab laboratories (San Francisco, US).

147 Three mitochondrial genes (12S rRNA; 16S rRNA; Cytochrom oxygnese subunit 1 (COI)) and

148 four nuclear genes (18S rRNA; 28S rRNA, Internal transcribed spacer (ITS); Histon 3 (H3))

149 were chosen for analysis. For phylogenetic inference of all seven gene partitions, we used

150 Ephyrina figueirai Crosnier \& Forest, 1973 (family: Acanthephyridae), and Palaemon

151 elegans Rathke, 1837 (family: Palaemonidae), as outgroup species that belong to the Caridea, the

152 same infraorder of Typhlocaris, because sequences of the seven genes used in our analysis were

153 available in GenBank. Considering that both Palaemon and Typhlocaris belong to the same

154 superfamily (Palaemonoidea), and since Palaemonoidea is paraphyletic (Kou et al. 2013), E.

155 figueirai was chosen as a root node.

156 The Typhlocaris sequences were deposited in the GenBank under accession numbers

157 KY593415-KY593454. In addition to the newly generated sequences, two sequences of $T$.

158 salentina were obtained from GenBank and included in the molecular analysis. The list of taxa,

159 localities and GenBank accession numbers included in the analysis is detailed in the

160 Supplemental Information (Table S2). 
162 Sequence alignment was conducted using ClustalX embedded in MEGA v6.0 (Tamura et al.

163 2013).The sequences were concatenated to form a multi-gene matrix using Geneious v7.1 (http://

164 www.geneious.com/), including the three Typhlocaris sequences and two outgroups, delimited

165 into seven partitions, one for each gene. MEGA v6.0 (Tamura et al. 2013) was used in order to

166 select the best fitting substitution model for each partition according to the Bayesian Information

167 Criterion (Table 1).

168 Maximum likelihood analysis of the aligned partitions was conducted using RAxML v8.2.9

169 (Stamatakis 2014) on XSEDE server in the CIPRES Science Gateway portal (Miller et al. 2010)

170 using a GTRCAT model of evolution with 50 rate categories with 1000 bootstrapping replicates.

171 Bayesian Metropolis coupled Markov chain Monte Carlo (B-MCMC) analyses were conducted

172 with MrBayes v3.2 on XSEDE with GTR model (Ronquist et al. 2012). Search was conducted

173 with four chains (three cold, one hot) with trees sampled every 100 generations. Three 100

174 generations analyses were conducted to verify likelihood convergence and burn-in parameter.

\section{Estimation of evolutionary rates}

176 Since the molecular clock calculations for cave-dwelling species are often contentious (Page et

177 al. 2008), we used multiple genes and a relaxed molecular clock approach (Drummond et al.

178 2006). To estimate the divergence time of Typhlocaris species, we first performed analyses

179 based on accepted molecular evolution rates of the mitochondrial genes COI and 16S rRNA for

180 crustaceans: 0.0140 nucleotide substitutions per Myr (Knowlton \& Weigt 1998), and 0.0090

181 substitutions per Myr (Sturmbauer et al. 1996). As an alternative approach, we used a calibrated

182 tree based on a regional geological event. A similar approach was applied by Bauzà-Ribot et al.

183 (2012) that used two paleogeographic events as a calibration point to establish the divergence

184 pattern of the stygobiont family Metacrangonyctidae (Amphipoda). The top of Bira formation,

185 dated to $7 \mathrm{Ma}$ (Rozenbaum et al. 2016), marks the end of the marine connection between the

186 Mediterranean and the Dead Sea valley. Therefore we assume that this event indicates the

187 isolation of T. galilea from its sister taxa, and we used it as a calibration node. Using Bira

188 formation as a calibration node, solely allowed the estimation of the divergence time of the sister

189 species, T. ayyaloni and T. salentina, and thus infer the geological event that led to this

190 separation. 
191 Bayesian evolutionary analysis was used to obtain the evolutionary rates of COI and 16S genes

192 under the favored tree topology, based on the ML analysis. A relaxed-clock MCMC approach

193 using the uncorrelated log-normal model was implemented in BEAST v2.4 (Drummond \&

194 Bouckaert 2015) on XSEDE server in the CIPRES Science Gateway portal (Miller et al. 2010),

195 using 10 million generations, and sampling every 1000th generation. Models of sequence

196 evolution for each gene were determined using the corrected Akaike information criterion in

197 JModelTest v2.1 (Darriba \& Posada 2014, Table 2) on XSEDE server. The Yule process was

198 chosen as speciation process for both genes. Log files were analyzed with Tracer v1.6 (Rambaut

199 et al. 2015), to assess convergence and confirm that the combined effective sample sizes for all

200 parameters were larger than 200, in order to ensure that the MCMC chain had run long enough to

201 get a valid estimate of the parameters (Drummond \& Rambaut 2007). All resulting trees were

202 then combined with LogCombiner v1.8.2, with a burn-in of 25\%. A maximum credibility tree

203 was then produced using TreeAnnotator v2.1.2 (Rambaut \& Drummond 2015).

\section{RESULTS}

205 The concatenated alignment of the seven genes was $7761 \mathrm{bp}$ long, out of which 1645 were

206 parsimonious informative. The substitution models selected for all the genes/partitions with the

207 corrected Akaike Information Criterion and the Bayesian Information Criterion scores is

208 presented in Table 1. Figure 3 presents a maximum likelihood (ML) tree of the concatenated

209 sequences, showing that $T$. salentina and T. ayyaloni are more closely related to each other than

210 either of them is to T. galilea. Out of the seven genes used for the analysis, five gene sequences

211 (ITS, 28S, COI, 12S, 16S) presented this topology. The remaining gene trees, of 18S and H3,

212 had slightly different topology. However, the bootstrap support of the nodes connecting

213 Typhlocaris species in these two trees was less than 50\%. The topology of the five gene

214 phylogenetic tree supports the hypothesis suggesting that T. galilea was separated from its

215 presumed marine ancestor earlier than the separation of T. ayyaloni and T. salentina (H2, Figure

$2162)$.

217 Using the common evolutionary rates for crustacean COI and 16S genes, 0.0140 and 0.0090

218 substitutions/Myr, respectively (Knowlton \& Weigt 1998; Sturmbauer et al. 1996), the

219 divergence time estimations for T. galilea and T. salentina-T.ayyaloni clade were 3.7 [3.0-4.5] 
220 and 3.3 (2.3-4.2) Ma, respectively (means [95\% highest probability density intervals]). The

221 divergence time between T. ayyaloni and T. salentina was estimated as 3.2 (2.4-3.8) Ma

222 according to COI and as $2.6(1.6-3.4)$ according to $16 \mathrm{~S}$ (Table 2). These estimations suggest that

223 the divergence of Typhlocaris species has happened two million years after the Zanclean

224 reflooding of the Mediterranean Sea, thus under no apparent vicariant conditions.

225 Using $7 \mathrm{Ma}$ as the detachment time that isolated T. galilea from the Mediterranean Sea (top Bira

226 formation), the divergence time of T. ayyaloni and T. salentina was according to COI gene -6.0

227 [4.5-7.2] Ma and according to the $16 \mathrm{~S}$ gene -5.9 [3.6-7.4] Ma (Table 2), suggesting that these

228 are relicts of the last high level of the Mediterranean Sea before the MSC. The computed

229 evolutionary rates for COI -0.0077 substitutions/Myr and for $16 \mathrm{~S}-0.0046$ substitutions/Myr,

230 are notably lower than the molecular clock rates found in previous crustacean studies (Table 3).

231 The evolutionary rates of ITS, $28 \mathrm{~S}$, and $12 \mathrm{~S}$ were $0.0104,0.0184,0.0115$ substitutions/Myr,

232 respectively.

233 DISCUSSION

234 Marine regressions are the most significant vicariant events forming physical barriers and

235 structuring stygoboint speciation (Boutin \& Coineau 2012; Culver et al. 2009; Notenboom 1991;

236 Porter 2007; Stock 1993). Other influential vicariant events include uplilft of mountain ridges

237 (Bauzà-Ribot et al. 2012; Humphreys \& Danielopol 2005; Reid et al. 2002), and events that

238 destroy or close off aquatic dispersal corridors (Barr \& Holsinger 1985; Holsinger 2012). Using

239 molecular techniques, we established the phylogeny of Typhlocaris species, and showed that $T$.

240 salentina (Italy) and T. ayyaloni (Israel) are sister species, both sister to T. galilea (Israel). These

241 phylogeographic relationships indicated that more than one vicariant event have shaped the

242 speciation pattern of Typhlocaris. First, T. galilea was tectonically isolated from the

243 Mediterranean Sea by the arching uplift of the central mountain range of Israel, $~ 7 \mathrm{Ma}$ (Matmon

244 et al. 2003; Wdowinski \& Zilberman 1997). Later, T. ayyaloni and T. salentina were stranded

245 and separated by a marine regression $\sim 6 \mathrm{Ma}$, as a result of the Messinian Salinity Crisis.

246 The fourth Typhlocaris species, T. lethaea, was missing from our analysis due to the

247 inaccessibility of Lete Cave, Libya, where it is found. Hypothetically, adding T. lethaea to the 
248 phylogenetic analysis, could have resulted in a modified tree topology, and potentially, in

249 different scenario of speciation (e.g., finding that T. galilea and T. lethaea are sister species will

250 compel a modification of the inferred speciation model). The long branch of one of the $T$.

251 salentina specimens likely reflects the difference between populations originating in different

252 cave systems in southern Italy, where the samples were collected (Lu Bissu and Mola di Bari

253 caves). Both the effect of T. lethaea on the phylogeographic pattern of Typhlocaris, and the

254 population genetics of $T$. salentina in the caves and wells of Salento and southern Murge karst

255 systems, warrant each for an independent study.

256 Commonly, the final closure of the Isthmus of Panama that has occurred approximately $3 \mathrm{Ma}$

257 (Coates et al. 1992; Keigwin 1982; Keigwin 1978; O’Dea et al. 2016) is used for estimation and

258 calibration of divergence time of crustaceans. Knowlton and Weigt (1998) and Williams et al.

259 (2001) found that the substitution rate of COI is 0.0140 per Myr. This finding is based on the

260 pairs of transisthmian snapping shrimp Alpheus from Panama: A. estuarensis - A. colombiensis,

261 and A. nepenulitimus - A. chacei. Schubart et al. (1998) calibrated the substitution rate of $16 \mathrm{~S}$

262 rDNA using trans-isthmian pairs of crabs of the genus Sesarma (Grapsidae) and then used this

263 rate to estimate a date for the origin of the Jamaican lineage Sesarma, the substitution rate of

264 Sesarma was 0.0065 per Myr. Sturmbauer et al. (1996) used the same gene from populations of

265 the fiddler crab Uca vocator, from either side of the Isthmus of Panama to estimate divergences

266 rates of $U c a$. The sequence divergence rate was 0.0090 per Myr; this rate was used to estimate

267 the time divergence between clades of terrestrial Uca from different parts of the globe.

268 Craft et al. (2008) and Page et al. (2008) that studied the phylogeography of atyids did not use

269 the rates of transisthmian organisms to calibrate the molecular clock but estimated it

270 independently for the studied taxa. Craft et al. (2008) studied Halocaridina from the Hawaiian

271 Archipelago. To calibrate the molecular clock, they used the age of the earliest eruption

272 of Kilauea volcano in Hawaii, 50-100 Ka, and the genetic data of the groups of

273 Halocaridina that occur along the flank of this volcano. They found an exceptionally

274 high divergence rate of 0.2 per Myr in COI gene of Halocaridina. They noted that this rate is

275 in sharp contrast to the commonly utilized evolution rates for arthropods 0.0140-0.0170 per Myr

276 (Williams et al. 2001). Page et al. (2008) studied the cave atyids Stygiocaris from Cape Range

277 area in Western Australia. It is accepted that the emergence of the Cape Range Anticline in the 
278 Miocene isolated Stygiocaris lancifera and S. stylifera, leading to their speciation, therefore, 279 Page et al. (2008) used this event, 7-10 Ma, as a calibration point to estimate rates of molecular 280 divergence. This yielded a wide range of evolutionary rates for the S. lancifera / stylifera node: $2810.0133-0.0516$ substitutions/Myr in COI and 0.0055-0.0103 substitutions/Myr in 16S, relatively 282 lower than other atyid studies, but still higher than the rate we found for Typhlocaris.

283 Our estimated low evolutionary rates in Typhlocaris correspond with the analysis of Zakšek et al. 284 (2009) that studied the phylogeography the cave shrimp Troglocaris anophthalmus. To estimate 285 the divergence time they referred to the divergence rate of COI used for transisthmian species of 286 Alpheus across the Isthmus of Panama (Knowlton and Weigt, 1998). Zakšek et al. (2009), 287 therefore, stated that for Troglocaris, the rate calculated by Knowlton and Weigt (1998) can be 288 used only for estimation of the order of magnitude of divergence time because it is the most commonly used rate for decapods. Nonetheless, they found COI patristic distances between phylogroups that are much lower (0.05-0.08) than the accepted patristic COI distance of 0.16 substitutions per nucleotide position found to optimally separate intra-from interspecies 292 divergence in other crustaceans (Lefébure et al. 2007).

293 The rates found by us are in one order of magnitude lower than those found for Alpheus, the 294 common crustacean used for calibration of divergence time (Knowlton \& Weigt 1998), and 295 lower or similar to the rates of other stygobionts (Table 3). An exception is the case of the stygobiont amphipod family Metacrangonyctidae, which was shown to undergo rapid evolution using mitochondrial protein-coding genes (Bauzà-Ribot et al. 2012). The average rate estimated

298 by Bauzà-Ribot et al. was 0.1090 substitutions/Myr, one order of magnitude higher than the rates acceptable for other crustaceans. They suggested that this high rate might result from frequent population bottlenecks. Evolutionary rates, even of the same gene, may vary between different genera within the same order -indicating that evolutionary rates are not related only to the taxonomic position but also, or mainly, to ecological conditions. We therefore did not use the previously reported substitution rate but the known geological data of the area where Typhlocaris occurs to infer its divergence rate and time. The lower divergence rates found for Typhlocaris compared with other crustaceans lead us to the suggestion that the low rates are related to the ecological conditions of the Typhlocaris habitat. Typhlocaris and other stygobionts are found in isolated subterranean basins where species diversity is very low, relative to the regional diversity 
308 (Gibert et al. 2009), reducing interspecific competition. The environmental factors in these

309 habitats are stable, lacking fluctuations. Predators are typically missing in subterranean habitats,

310 resulting in truncated food webs (Gibert \& Deharveng 2002). Additionally, evolution rates were

311 correlated with metabolic rates (Martin \& Palumbi 1993). Species with low metabolic rates (e.g.,

312 deep-sea fauna) are generally characterized by reduced nucleotide substitution rates. It was

313 hypothesized that limited light reduces visual predation pressure and selects for reduced

314 locomotory ability and metabolic capacity (da Silva et al. 2011). This may be just as well the

315 case of stygobiont evolution. Thus, the combined unique ecological and biological conditions

316 (dark habitat, environmental stability, low richness, lack of interspecific competition) may lead

317 to stability and low rate of gene divergence. This is in agreement with the statement of Mayr

318 (1963) that competition and allopatry are important elements of speciation and evolutionary

319 divergence.

320 Culver (1976) noted that the most striking feature of the organization of Appalachian cave-

321 stream communities is the reduction in intensity of competition. One of the suggested

322 explanations is that, with increasing time in caves, species evolve a life-history strategy of high

323 metabolic efficiency and low reproductive rate, a strategy that may itself reduce interspecific

324 competition. We thus may assume that the higher divergence rates found in non-stygobiont

325 crustaceans are related to competition. The classical taxa used for calibration of molecular dating

326 are the 18 species of Alpheus at both sides of the Isthmus of Panama (Knowlton and Weigt,

327 1998). Knowlton (1993) observed aggressive behavior among species including individuals that

328 belong to a nominal species from both sides of the Isthmus of Panama, supporting our

329 assumption on the role of competition in delimiting evolutionary rates.

330 Using evolutionary biology, we can identify processes that promote or maintain phenotypic and

331 genetic diversity in natural populations. This is of a great importance particularly when the

332 studied organisms are under high risk of becoming extinct. While many studies confirmed that

333 interspecific competition and environmental variation drive genetic diversification, there is little

334 phylogeographic evidence linking environmental stability with low genetic variation. Further

335 molecular investigations of stygobionts and other organisms of stable environments will shed

336 light on universality of their temporal mode of speciation. 
339 Our results indicated that two separate vicariant event shaped the distribution patterns of the

340 blind cave-dwelling shrimp Typhlocaris. During the late Miocene, T. galilea was tectonically

341 isolated from the Mediterranean Sea by the arching uplift of the central mountain range of Israel,

342 ca. 7 Ma. During the Messinian Salinity Crisis, T. ayyaloni, geographically adjacent to T. galilea,

343 and T. salentina were stranded and separated by a marine transgression. A future investigation of

344 the divergence time of T. lethaea may shed more light on the transgression events leading to the

345 disjunct phylogeographic pattern of Typhlocaris. Furthermore, the evolutionary rates of

346 Typhlocaris estimated in this study (0.0077 substitutions/Myr in Cytochrome Oxidase Subunit 1

347 (COI) and 0.0046 substitutions/Myr in 16S rRNA) were in one order of magnitude lower than

348 the rates of closely related crustaceans, and lower than other stygobiont species. These low rates

349 may result from the low predation stress and the low diversity, leading to low interspecific

350 competition, which characterizes the highly isolated subterranean habitats inhabited by

351 Typhlocaris.

\section{ACKNOWLEDGEMENTS}

353 We thank Dr. G. Messana Firenze of Instituto per lo Studio degli Ecosistemi, Florence, Italy, for 354 providing specimens of Typhlocaris salentina from Lu Bissu cave and Mola di Bari cave. The 355 Museum National d'Histoire Naturelle in Paris for the use of T. lethaea specimens. Dr. Hanan 356 Dimentman for assisting with the study of T. ayyaloni. Francisco R. Barboza and Markus Franz

357 for helping with map preparation. We thank the anonymous reviewers for their valuable 358 comments and in helping to improve the manuscript. This article is dedicated to the memory of

359 Prof. Francisc D. Por, who initiated the study of relict aquatic fauna of the Jordan rift valley.

\section{REFERENCES}

361

362

363

364

365
Barr TC, and Holsinger JR. 1985. Speciation in cave faunas. Annual Review of Ecology and Systematics 16:313-337.

Bauzà-Ribot MM, Juan C, Nardi F, Oromí P, Pons J, and Jaume D. 2012. Mitogenomic phylogenetic analysis supports continental-scale vicariance in subterranean thalassoid crustaceans. Current Biology 22:2069-2074. 
366 Boutin C, and Coineau N. 2012. Marine regressions. Encyclopedia of Caves (Second Edition): Elsevier, 482-486.

368 Calman WT. 1909. On a Blind Prawn from the Sea of Galilee (Typhlocaris galilea). Transactions of the Linnean Society of London 2nd Series: Zoology 11:93-97.

Christman MC, Culver DC, Madden MK, and White D. 2005. Patterns of endemism of the eastern North American cave fauna. Journal of Biogeography 32:1441-1452.

Coates AG, Jackson JB, Collins LS, Cronin TM, Dowsett HJ, Bybell LM, Jung P, and Obando JA. 1992. Closure of the Isthmus of Panama: the near-shore marine record of Costa Rica and western Panama. Geological Society of America Bulletin 104:814-828.

374

375

376

377

378

379

380

381

382

383

384

385

386

387

388

389

390

391

392

393

394

Craft JD, Russ AD, Yamamoto MN, Iwai TY, Hau S, Kahiapo J, Chong CT, Ziegler-Chong S, Muir C, and Fujita Y. 2008. Islands under islands: The phylogeography and evolution of Halocaridina rubra Holthuis, 1963 (Crustacean: Decapoda: Atyidae) in the Hawaiian archipelago. Limnology and Oceanography 53:675-689.

Culver DC. 1976. The evolution of aquatic cave communities. The American Naturalist 110:945957.

Culver DC, and Holsinger JR. 1992. How many species of troglobites are there. National Speleological Society Bulletin 54:79-80.

Culver DC, and Pipan T. 2009. The biology of caves and other subterranean habitats: OUP Oxford.

Culver DC, Pipan T, and Schneider K. 2009. Vicariance, dispersal and scale in the aquatic subterranean fauna of karst regions. Freshwater Biology 54:918-929.

Culver DC, and Sket B. 2000. Hotspots of subterranean biodiversity in caves and wells. Journal of Cave and Karst Studies 62:11-17.

da Silva JM, Creer S, Dos Santos A, Costa AC, Cunha MR, Costa FO, and Carvalho GR. 2011. Systematic and evolutionary insights derived from mtDNA COI barcode diversity in the Decapoda (Crustacea: Malacostraca). PLoS one 6:e19449.

Danielopol DL, Griebler C, Gunatilaka A, and Notenboom J. 2003. Present state and future prospects for groundwater ecosystems. Environmental Conservation 30:104-130.

Darriba D, and Posada D. 2014. jModelTest 2.0 Manual v0. 1.1.

De Grave S. 2013. Typhlocaris. The IUCN Red List of Threatened Species 2013.

Drummond AJ, and Bouckaert RR. 2015. Bayesian evolutionary analysis with BEAST: Cambridge University Press. 
398

399

400

401

402

403

404

405

406

407

408

409

410

411

412

413

414

415

416

417

418

419

420

421

422

423

424

425

426

427

428

429

430

431

Drummond AJ, Ho SY, Phillips MJ, and Rambaut A. 2006. Relaxed phylogenetics and dating with confidence. PLoS biology 4 :e88.

Drummond AJ, and Rambaut A. 2007. BEAST: Bayesian evolutionary analysis by sampling trees. BMC evolutionary biology 7:1.

Froglia C, and Ungaro N. 2001. An unusual new record of Typhlocaris salentina (Caroli, 1923)(Decapoda: Typhlocarididae) from subterranean water of Apulia (southern Italy). Atti della Società Italiana di Scienze Naturali e del Museo Civico di Storia Naturale di Milano 142:103-108.

Gibert J, Culver DC, Dole-Olivier MJ, Malard F, Christman MC, and Deharveng L. 2009. Assessing and conserving groundwater biodiversity: synthesis and perspectives. Freshwater Biology 54:930-941.

Gibert J, and Deharveng L. 2002. Subterranean ecosystems: a truncated functional biodiversity. BioScience 52:473-482.

Holsinger JR. 2012. Vicariance and dispersalist biogeography. Encyclopedia of Caves (Second Edition): Elsevier, 849-858.

Horowitz A. 2001. The Jordan rift valley: Taylor \& Francis.

Humphreys W, and Danielopol D. 2005. Danielopolina (Ostracoda, Thaumatocyprididae) on Christmas Island, Indian Ocean, a sea mount island. Crustaceana 78:1339-1352.

Keigwin L. 1982. Isotopic paleoceanography of the Caribbean and East Pacific: role of Panama uplift in late Neogene time. Science 217:350-353.

Keigwin LD. 1978. Pliocene closing of the Isthmus of Panama, based on biostratigraphic evidence from nearby Pacific Ocean and Caribbean Sea cores. Geology 6:630-634.

Ketmaier V, Argano R, and Caccone A. 2003. Phylogeography and molecular rates of subterranean aquatic Stenasellid Isopods with a peri-Tyrrhenian distribution. Molecular Ecology 12:547-555.

Knowlton N. 1993. Sibling species in the sea. Annual review of ecology and systematics 24:189216.

Knowlton N, and Weigt LA. 1998. New dates and new rates for divergence across the Isthmus of Panama. Proceedings of the Royal Society of London B: Biological Sciences 265:22572263.

Kou Q, Li X, Chan T-Y, Chu KH, and Gan Z. 2013. Molecular phylogeny of the superfamily Palaemonoidea (Crustacea: Decapoda: Caridea) based on mitochondrial and nuclear DNA reveals discrepancies with the current classification. Invertebrate systematics 27:502-514. 
432 Lefébure T, Douady C, Malard F, and Gibert J. 2007. Testing dispersal and cryptic diversity in a

433

434

435

436

437

438

439

440

441

442

443

444

445

446

447

448

449

450

451

452

453

454

455

456

457

458

459

460

461

462

463

464 widely distributed groundwater amphipod (Niphargus rhenorhodanensis). Molecular phylogenetics and evolution 42:676-686.

Martin AP, and Palumbi SR. 1993. Body size, metabolic rate, generation time, and the molecular clock. Proceedings of the National Academy of Sciences 90:4087-4091.

Matmon A, Wdowinski S, and Hall J. 2003. Morphological and structural relations in the Galilee extensional domain, northern Israel. Tectonophysics 371:223-241.

Mayr E. 1963. Animal speciation and evolution. Cambridge, Massachusetts: Harvard University Press.

Miller MA, Pfeiffer W, and Schwartz T. 2010. Proceedings of the Gateway Computing Environments Workshop (GCE). Creating the CIPRES science gateway for inference of large phylogenetic trees, 1-8.

Notenboom J. 1991. Marine regressions and the evolution of groundwater dwelling amphipods (Crustacea). Journal of Biogeography:437-454.

O’Dea A, Lessios HA, Coates AG, Eytan RI, Restrepo-Moreno SA, Cione AL, Collins LS, de Queiroz A, Farris DW, and Norris RD. 2016. Formation of the Isthmus of Panama. Science Advances 2:e1600883.

Page TJ, Humphreys WF, and Hughes JM. 2008. Shrimps down under: evolutionary relationships of subterranean crustaceans from Western Australia (Decapoda: Atyidae: Stygiocaris). PLoS One 3:e1618.

Por F. 1963. The relict aquatic fauna of the Jordan Rift Valley: new contributions and review. Israel Journal of Zoology 12:47-58.

Por F. 1975. An outline of the zoogeography of the Levant. Zoologica Scripta 4:5-20.

Por F. 1986. Crustacean Biogeography of the Late Middle Miocene Middle Eastern Landbridge. Crustacean Issues 1986.

Por F, Dimentman C, Frumkin A, and Naaman I. 2013. Animal life in the chemoautotrophic ecosystem of the hypogenic groundwater cave of Ayyalon (Israel): A summing up. Natural Science 5:7.

Por FD, and Dimentman C. 2006. Mare Nostrum: Neogene and anthropic natural history of the Mediterranean basin, with emphasis on the Levant: Pensoft Pub.

Porter ML. 2007. Subterranean biogeography: what have we learned from molecular techniques. Journal of Cave and Karst Studies 69:179-186.

Rambaut A, and Drummond A. 2015. LogCombiner v1. 8.2. 
465 Rambaut A, Suchard M, Xie D, and Drummond A. 2015. Tracer v1. 6. beast bio ed ac

466 uk/Tracer.

467

468

469

470

471

472

473

474

475

476

477

478

479

480

481

482

483

484

485

486

487

488

489

490

491

492

493

494

495

496

497

498

499

Reid JW, Bayly IA, Pesce GL, Rayner NA, Reddy YR, Rocha CE, Suárez-Morales E, and Ueda H. 2002. Conservation of continental copepod crustaceans. Modern approaches to the study of Crustacea: Springer, 253-261.

Ronquist F, Teslenko M, van der Mark P, Ayres DL, Darling A, Höhna S, Larget B, Liu L, Suchard MA, and Huelsenbeck JP. 2012. MrBayes 3.2: efficient Bayesian phylogenetic inference and model choice across a large model space. Systematic biology 61:539-542.

Rozenbaum A, Sandler A, Zilberman E, Stein M, Jicha B, and Singer B. 2016. 40Ar/39Ar chronostratigraphy of late Miocene-early Pliocene continental aquatic basins in SE Galilee, Israel. Geological Society of America Bulletin 128:1383-1402.

Saiki R, Gelfand D, Stoffel S, Scharf S, Higuchi R, Horn G, Mullis K, and Ehrlich H. 1988. Primer-directed enzymatic amplification of DNA. Science 239:487-491.

Schubart CD, Diesel R, and Hedges SB. 1998. Rapid evolution to terrestrial life in Jamaican crabs. Nature 393:363.

Shaked-Gelband D, Edelman-Furstenberg Y, Mienis H, Sandler A, Zilberman E, Stein M, and Starinski A. 2014. Depositional Environments of the Bira Formation at Nahal Tavor from Macrofauna Analysis: Ministry of Energy and Water Earth-Science Administration Report ES-25-12. p 19.

Shaliv G. 1989. Stages in the tectonic and volcanic history of Neogene continental basins in northern Israel. Ph. D. Thesis, The Hebrew University, Jerusalem.

Stamatakis A. 2014. RAxML version 8: a tool for phylogenetic analysis and post-analysis of large phylogenies. Bioinformatics 30:1312-1313.

Stock J. 1993. Some remarkable distribution patterns in stygobiont Amphipoda. Journal of Natural History 27:807-819.

Sturmbauer C, Levinton JS, and Christy J. 1996. Molecular phylogeny analysis of fiddler crabs: test of the hypothesis of increasing behavioral complexity in evolution. Proceedings of the National Academy of Sciences 93:10855-10857.

Tamura K, Stecher G, Peterson D, Filipski A, and Kumar S. 2013. MEGA6: molecular evolutionary genetics analysis version 6.0. Molecular Biology and Evolution 30:27252729.

Tsurnamal M. 2008. A new species of the stygobiotic blind prawn Typhlocaris Calman, 1909 (Decapoda, Palaemonidae, Typhlocaridinae) from Israel. Crustaceana 81:487-501.

Wdowinski S, and Zilberman E. 1997. Systematic analyses of the large-scale topography and structure across the Dead Sea Rift. Tectonics 16:409-424. 
500 Williams S, Knowlton N, Weigt L, and Jara J. 2001. Evidence for three major clades within the

501

502

503

504

505

506

507

508

509

510

511 Figure 2. Schemes describing the two hypotheses of development of the disjunct distribution of

512

513

514

515

516

517

518

519

520

521

522

523

524

525

526

527 snapping shrimp genus Alpheus inferred from nuclear and mitochondrial gene sequence data. Molecular Phylogenetics and Evolution 20:375-389.

Zakšek V, Sket B, Gottstein S, Franjević D, and Trontelj P. 2009. The limits of cryptic diversity in groundwater: phylogeography of the cave shrimp Troglocaris anophthalmus (Crustacea: Decapoda: Atyidae). Molecular Ecology 18:931-946.

FIGURE LEGENDS

Figure 1. Distribution map of Typhlocaris species (colored in red) based on spatial data from NatureServe and IUCN (International Union for Conservation of Nature). The IUCN Red List of Threatened Species. Version 2014.1. (http://www.iucnredlist.org). Downloaded on 28 January 2018. Map made using Natural Earth data (http://www.naturalearthdata.com). Typhlocaris. H1: the peri-Mediterranean transgression scenario. H2: tectonic isolation of the eastern Galilee from the Mediterranean followed by stranding to the coastal aquifers by ingressions.

Figure 3. Multi-locus Maximum Likelihood tree of the genus Typhlocaris, based on combined $12 \mathrm{~S}$ rRNA + 16S rRNA + COI + 18S rRNA + 28S rRNA + ITS + H3 genes (total 7761 bp). At each node, the number above the branch indicates the percentage of ML bootstrap support (1000 replicates) from RAxML analysis with the GTRCAT model of evolution. The number below the branch at each node indicates the Bayesian posterior probability expressed as a decimal fraction for nodes that received at least 50\% support in at least one analysis. The scale bar denotes the estimated number of nucleotide substitutions per site.

\section{TABLE LEGENDS}

Table 1. Nucleotide analysis and substitution models selected (out of 24 candidate models) for all the genes/partitions.

Table 2. Divergence times (and 95\% CI) for Typhlocaris species as estimated using Bayesian evolutionary analysis method calculated using COI and 16S gene molecular evolution rates and using calibration based on Bira formation. 
528 Table 3. Comparison between the COI and $16 \mathrm{~S}$ molecular evolution rates estimated in this and

529 previous crustacean studies: ${ }^{[1]}$ this study, ${ }^{[2]}$ Knowlton \& Weigt (1998), ${ }^{[3]}$ Page et al. (2008), ${ }^{[4]}$

530 Schubart et al. (1998), ${ }^{[5]}$ Sturmbauer et al. (1996), ${ }^{[6]}$ Ketmaier et al. (2003), ${ }^{[7]}$ Craft et al.

531 (2008).

\section{SUPPLEMETAL INFORMATION - TABLE LEGENDS}

533 Table S1. List of the primers used for gene amplification in this study and PCR profiles.

534 Table S2. GenBank accession numbers of Typhlocaris.

\section{DATA ACCESSIBILITY STATEMENT}

536 The authors confirm that all data underlying the findings are fully available without restriction.

537 All DNA sequences generated in this research were deposited in the GenBank. The list of

538 primers used and designed for this study and the list of taxa, localities and GenBank accession

539 numbers are detailed in the Supplemental Information (Table S1 and S2, respectively) and will

540 be made available in the data repository PANGAEA. 


\section{Figure 1 (on next page)}

Distribution map of Typhlocaris species (colored in red) based on spatial data from NatureServe and IUCN (International Union for Conservation of Nature).

The IUCN Red List of Threatened Species. Version 2014.1. (http://www.iucnredlist.org). Downloaded on 28 January 2018. Map made using Natural Earth data (http://www.naturalearthdata.com). 


\section{Figure 2 (on next page)}

Schemes describing the two hypotheses of development of the disjunct distribution of Typhlocaris.

(A) $\mathrm{H} 1$ : the peri-Mediterranean transgression scenario. (B) H2: tectonic isolation of the eastern Galilee from the Mediterranean followed by stranding to the coastal aquifers by ingressions. 


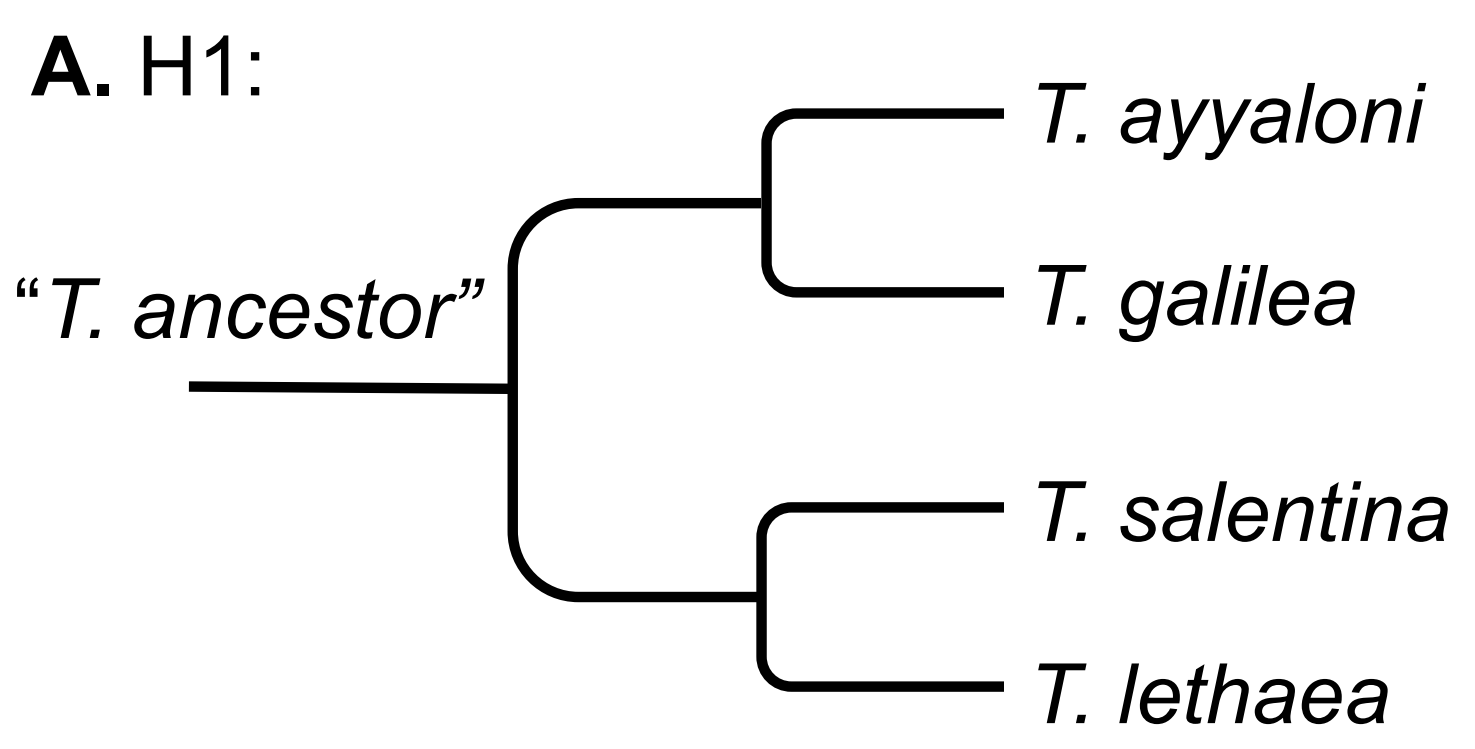

B. $\mathrm{H} 2$ :

T. ayyaloni

"T. ancestor"

T. galilea 
Figure 3 (on next page)

Multi-locus Maximum Likelihood tree of the genus Typhlocaris, based on combined $12 \mathrm{~S}$ rRNA + 16S rRNA + COI + 18S rRNA + 28S rRNA + ITS + H3 genes (total 7761 bp).

At each node, the number above the branch indicates the percentage of ML bootstrap support (1000 replicates) from RAXML analysis with the GTRCAT model of evolution. The number below the branch at each node indicates the Bayesian posterior probability expressed as a decimal fraction for nodes that received at least $50 \%$ support in at least one analysis. The scale bar denotes the estimated number of nucleotide substitutions per site. 


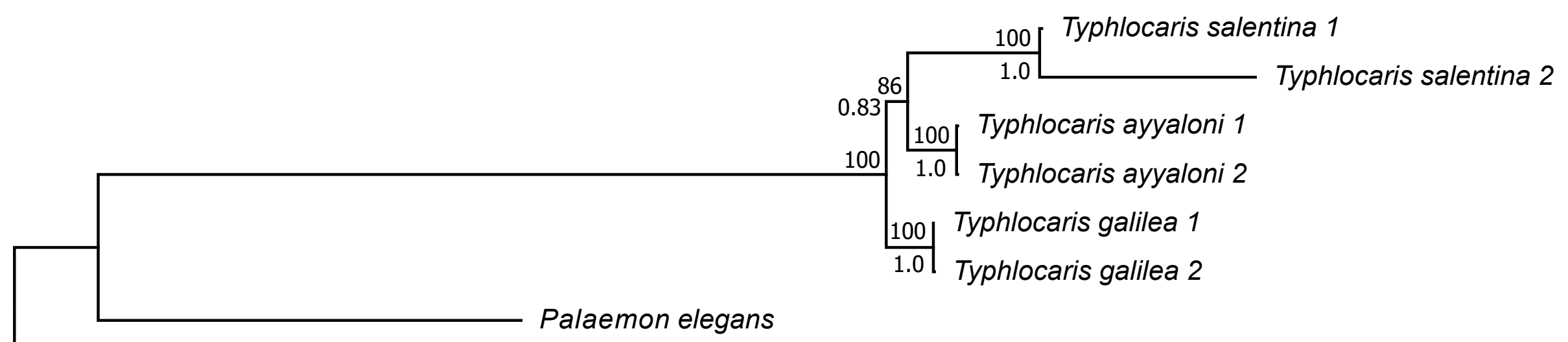

Ephyrina figueirai 


\section{Table $\mathbf{1}$ (on next page)}

Nucleotide analysis and substitution models selected (out of 24 candidate models) for all the genes/partitions. 


\begin{tabular}{cccccc}
\hline \hline Partition & $\begin{array}{c}\text { Length } \\
\text { (bp) }\end{array}$ & $\begin{array}{c}\text { Informative } \\
\text { Positions }\end{array}$ & $\begin{array}{c}\text { Variable } \\
\text { Positions }\end{array}$ & Model & Nst-rates \\
\hline 12S & 394 & 161 & 236 & T92+G & 6 - Gamma \\
16S & 972 & 160 & 221 & HKY $+\mathrm{G}$ & 2 - Gamma \\
COI & 663 & 254 & 286 & GTR+G+I & 6 - Gamma \\
18S & 1914 & 263 & 342 & K2+G & 2 - Gamma \\
28S & 2059 & 306 & 659 & T92+G & 6 - Gamma \\
ITS & 1795 & 612 & 1523 & T92+G & 6 - Gamma \\
H3 & 358 & 50 & 97 & K2+G & 2 - Gamma \\
\hline \hline
\end{tabular}

2 


\section{Table 2 (on next page)}

Divergence times (and 95\% Cl) for Typhlocaris species as estimated using Bayesian evolutionary analysis method calculated using $\mathrm{COI}$ and $16 \mathrm{~S}$ gene molecular evolution rates and using calibration based on Bira formation. 


\begin{tabular}{|c|c|c|c|c|c|}
\hline Clade divergence & Gene & $\begin{array}{c}\text { Node age (Myr) } \\
\text { [range] } \\
\text { non-calibrated }\end{array}$ & $\begin{array}{l}\text { Calibration } \\
\text { node }\end{array}$ & $\begin{array}{c}\text { Node age (Myr) } \\
\text { [range] } \\
\text { calibrated }\end{array}$ & $\begin{array}{c}\text { Posterior } \\
\text { probability }\end{array}$ \\
\hline Typhlocaris & $\begin{array}{l}\mathrm{COI} \\
16 \mathrm{~S}\end{array}$ & $\begin{array}{l}13.4(10.6-14.0) \\
19.1(16.5-22.2)\end{array}$ & - & $\begin{array}{l}19.9[17.3-22.5] \\
41.5[35.8-48.5]\end{array}$ & $\begin{array}{l}0.48 \\
1.00\end{array}$ \\
\hline $\begin{array}{l}\text { (T. ayyaloni }+T . \\
\text { salentina) }-T . \text { galilea }\end{array}$ & $\begin{array}{l}\mathrm{COI} \\
16 \mathrm{~S}\end{array}$ & $\begin{array}{l}3.7(3.0-4.5) \\
3.3(2.3-4.2)\end{array}$ & 7.0 (Bira) & & $\begin{array}{l}1.00 \\
1.00\end{array}$ \\
\hline T. ayyaloni - T. salentina & $\begin{array}{l}\mathrm{COI} \\
16 \mathrm{~S}\end{array}$ & $\begin{array}{l}3.2(2.4-3.8) \\
2.6(1.6-3.4)\end{array}$ & - & $\begin{array}{l}5.7[4.4-6.9] \\
5.8[3.5-7.2]\end{array}$ & $\begin{array}{l}0.76 \\
0.76\end{array}$ \\
\hline
\end{tabular}

2

3

4 


\section{Table 3(on next page)}

Comparison between the $\mathrm{COI}$ and $16 \mathrm{~S}$ molecular evolution rates estimated in this and previous crustacean studies.

${ }^{[1]}$ this study, ${ }^{[2]}$ Knowlton \& Weigt (1998), ${ }^{[3]}$ Page et al. (2008), ${ }^{[4]}$ Schubart et al. (1998), ${ }^{[5]}$ Sturmbauer et al. (1996), ${ }^{[6]}$ Ketmaier et al. ( 2003 ), ${ }^{[7]}$ Craft et al. (2008). 
1

\begin{tabular}{|c|c|c|c|c|}
\hline \multirow{2}{*}{ Gene } & \multicolumn{2}{|c|}{ Stygofauna } & \multicolumn{2}{|c|}{ Non-Stygofauna } \\
\hline & Species & Substitutions /Myr & Species & Substitutions /Myr \\
\hline \multirow[t]{3}{*}{ COI mtRNA } & Typhlocaris spp. ${ }^{[1]}$ & 0.0077 & Alpheus spp. ${ }^{[2]}$ & 0.0140 \\
\hline & Stygiocaris spp. ${ }^{[3]}$ & $0.0133-0.0516$ & Halocaridina spp. ${ }^{[7]}$ & 0.2000 \\
\hline & Stenasellus spp. ${ }^{[6]}$ & 0.0125 & & \\
\hline \multirow[t]{2}{*}{ 16S rRNA } & Typhlocaris spp. ${ }^{[1]}$ & 0.0046 & Sesarma spp. ${ }^{[4]}$ & 0.0065 \\
\hline & Stygiocaris spp. ${ }^{[3]}$ & $0.0055-0.0103$ & Uca spp. ${ }^{[5]}$ & 0.0090 \\
\hline
\end{tabular}

2

3 